\title{
25. QUATERNARY AND NEOGENE FORAMINIFERA: BIOSTRATIGRAPHY
}

\author{
Barbara Zobel, Bundesanstalt für Bodenforschung, Hannover-Buchholz, Germany
}

\section{INTRODUCTION}

\section{Material Available}

About 600 samples of quaternary and Neogene sediment were collected during DSDP Leg 25 in order to establish biostratigraphic zones by means of foraminifera. From these 600 samples, about 350 have been examined under the microscope. Except for Site 249, where the Quaternary and Neogene section was cored continuously, coring of the young sediments was of ten discontinuous (Table 1).

TABLE 1

Quaternary and Neogene Sediment, Leg 25

\begin{tabular}{lcrc}
\hline Site & $\begin{array}{c}\text { Thickness } \\
(\mathrm{m})\end{array}$ & $\begin{array}{c}\text { Cored } \\
(\mathrm{m})\end{array}$ & $\begin{array}{c}\text { Recovery } \\
(\%)\end{array}$ \\
\hline 239 & 190 & 80 & 42 \\
240 & 170 & 27 & 16 \\
241 & 450 & 100 & 22 \\
242 & 500 & 60 & 12 \\
245 & 26 & 8 & 31 \\
246 & 130 & 1 & $<1$ \\
248 & 270 & 20 & 7 \\
249 & 170 & 140 & 82 \\
\hline
\end{tabular}

\section{Preservation of Cored Material}

Usefulness of the cored material for biostratigraphical and paleontological investigations is hampered by two factors: (1) the variable degree of calcium carbonate dissolution (Table 2); and (2) mechanical mixing during the

TABLE 2

Percentage of Core Deformation, Quaternary and Neogene Sediments

\begin{tabular}{cc}
\hline Site & $\begin{array}{c}\text { Deformed } \\
(\%)\end{array}$ \\
\hline 239 & 100 \\
240 & 100 \\
241 & 60 \\
242 & 50 \\
245 & 40 \\
246 & 100 \\
248 & 90 \\
249 & 27 \\
\hline
\end{tabular}

Note: This is based on hole descriptions. coring process, which is also variable (Table 3). Although the mixing in some cores destroyed only the sedimentary structures, sometimes, especially in the uppermost cores of a hole, the sediment was totally mixed and useless for biostratigraphy.

TABLE 3

Average Preservation of Foraminifera in Quaternary and Neogene Core Samples

\begin{tabular}{l|cccc}
\hline \multirow{2}{*}{ Site } & \multicolumn{4}{|c}{ Preservation of Foraminifera in Cores (Sections) } \\
\cline { 2 - 5 } & Good & Moderate & \multicolumn{1}{c}{ Poor } & No Forams \\
\hline $239^{\mathrm{a}}$ & \multicolumn{5}{|c}{1} & $2-9^{\mathrm{a}}$ & $11-13$ \\
$240^{\mathrm{a}}$ & $1(1)$ & $1(2)$ & $1(3), 4$ & 3,5 \\
$241^{\mathrm{b}}$ & 1 & $2-8^{\mathrm{b}}$ & $9-16^{\mathrm{b}}$ & \\
242 & $1-3$ & $4-7$ & & 1 \\
245 & & & & \\
246 & $1,2,3$ & 4 & & \\
$248^{\mathrm{a}}$ & \multicolumn{5}{c}{2} & 2, CC-6 & 8,9 \\
249 & $1-16(2)$ & & & \\
\hline
\end{tabular}

Note: Individual samples vary greatly. The qualitative descriptions are based on site reports. Numbers in parentheses are sections.

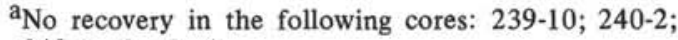
$248-1,-3,-5,-7$

${ }^{b_{S}}$ Site 241: Preservation in the cores is quite variable; evaluation based on the majority of samples in the core.

Although total mixing, such as that documented by faunal and floral evidence, is seldom found, caution is necessary in dealing with samples from all deformed cores, especially those from the very soft uppermost Quaternary sediment.

There is a good correlation between the degree of preservation of foraminifera and the depth in the hole, the Quarternary and Neogene sediment thickness, and the water depth of the site. Apparently, conditions for sediment deposition must not have changed significantly during the Neogene and Quaternary at the sites discussed (Figure 1).

Critical examination of the quality of the late Cenozoic foraminiferal material sampled during Leg 25 shows that detailed faunal analyses of the foraminifera from Sites 239 (partly), 240,245, and 248 are of limited value because of poor preservation and incomplete faunas. Biostratigraphic zonation of the sediments of these sites is possible, at least in part, by using the foraminifers remaining. However, no findings leading to improvement of the worldwide zonation scheme should be expected. The same is true for the 
core length

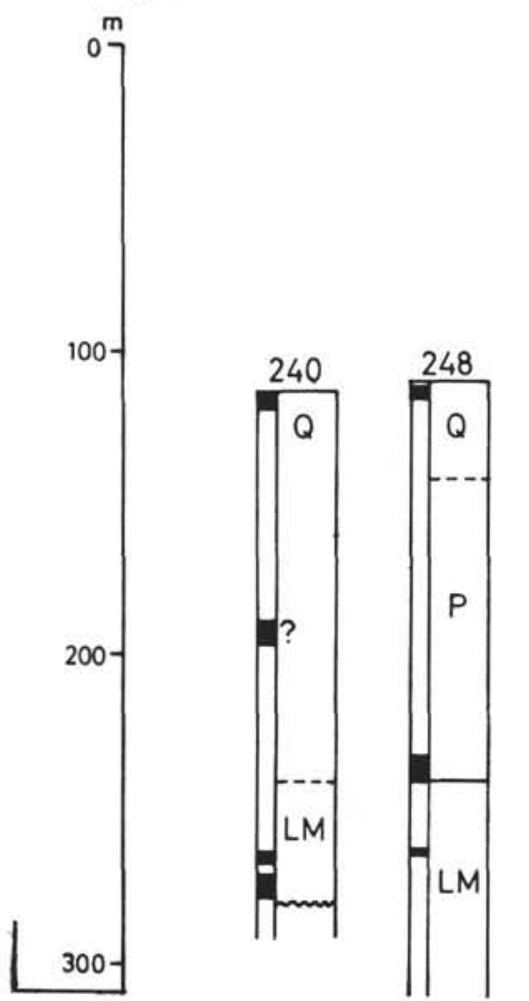

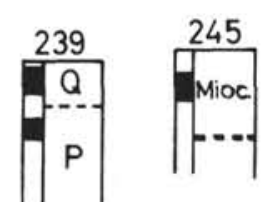

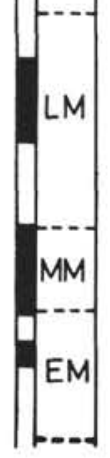

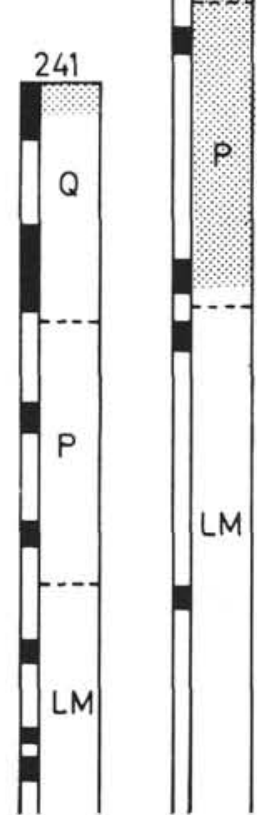

water depth of site

m

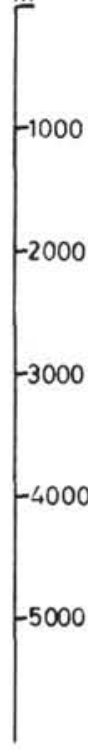

Figure 1. Preservation of Late Cenozoic foraminifera and present water depths of the sites of Leg 25 DSDP.

sediments of Sites 241 and 242, older than late Miocene. At these two sites, the samples with well-preserved foraminifera are, in most cases, from cores which were deformed during drilling. Both sites yield few individual samples with well-preserved and apparently complete foraminiferal assemblages from middle and early Miocene sediments.

As mentioned in the site report chapter, Site 239 contains sediments of a special facies with faunas which are unknown to the author and need very detailed study.

The only sediments with excellently preserved foraminifera are from Sites 246 and 249 , both of which are well above the calcium carbonate compensation depth (CCD). Due to technical difficulties, core recovery at Site 246 was extremely poor. Thus, only Site 249 remains promising for a detailed study of late Miocene biostratigraphy in the western Indian Ocean. This will be the purpose of a future study.

\section{RESULTS OF BIOSTRATIGRAPHIC INVESTIGATIONS}

\section{Zonation Scheme Used}

As already mentioned in the introduction to the site reports, the framework for biostratigraphic subdivision of Neogene sediments was taken from Blow (1969). Like every other more or less artificial system, that of Blow has both advantages and disadvantages. One of the shortcomings is the difficulty in recognizing the transition from one closely related species and/or subspecies used by Blow for one consecutive-range zone to another used for the next zone. This is often highly subjective (for instance Zone N.17 "horizon of the first evolutionary appearance of Globorotalia (G.) tumida plesiotumida from its immediate ancestor G. (G.) merotumida"). Another serious disadvantage is the nomenclature by numbers which makes improvements of the zonation system by obliteration or addition impossible. However, the designation of zones according to their guide fossils has its disadvantages as well because homonym zones may have been erected. For instance, the Globoquadrina altispira Zone of Bolli (1966a) is characteristic of the uppermost late Miocene, whereas, a zone of the same name (Jenkins and Orr, 1972) has an age between middle and late Miocene.

The writer does not wish to enter the discussion about optimal zonal boundaries and the most suitable name for existing biostratigraphic units. Therefore, advantage is taken of Blow's very suitable stratigraphic range charts (Blow, 1969, pp. 265-277). Such charts, if they are kept up to data and if the species used in them are clearly and unmistakably identifiable, seem to be the best means for 
worldwide recognition and correlation of biostratigraphic zones.

\section{Neogene Biostratigraphy}

The foraminifera used to recognize the zones given in Blow's (1969) range charts are listed in this short review of the Neogene biostratigraphic units in the cores collected during Leg 25. The foraminifera were determined by comparison with material kindly supplied to the author by Drs. Bolli and Beckmann, to both of whom, as well as to Dr. Sigal, the author is indebted for valuable advice.

\section{Early Miocene (Blow's Zones N.4-N.8)}

Foraminifera used for biostratigraphic zonation

Early early Miocene (N.4-N.5/6): Globigerina binaiensis, G. rohri, Globorotalia kugleri, G. mayeri, Globoquadrina altispira altispira, Gq. dehiscens dehiscens, and Globigerinita dissimilis.

Late early Miocene (N.6-N.8): Globigerinoides sicanus, Globorotalia fohsi peripheroronda, G. mayeri, Globoquadrina altispira altispira, Gq. dehiscens dehiscens, Gq. dehiscens advena, Globigerinatella insueta (only once), and Praeorbulina spp.

Occurrence of Early Miocene Sediments

Site 239: Questionable Globorotalia kugleri were found in Core 9; besides these, no characteristic foraminifera were found and/or cores are missing.

Site 240: Not present.

Site 241: Zone N.8 determined in Core 15, CC; Zone N.4N.3 in Core 16, Section 2 in bad preservation.

Site 242: Zones N.4 to N.6 in Core 8; individual preservation is fairly good, but the fauna seems to be incomplete. Zone N.8 was found in Core 7, CC. Between Core 7 and Core 8 , about 70 meters were drilled. Thus, the early Miocene at this site is complete, but the sediments were mostly not cored.

Site 245: Not present.

Site 246: A characteristic assemblage of Zone N.4 together with Eocene foraminifera were found in the only sample from Core 4.

Site 248: Not present.

Site 249: Not present.

\section{Middle Miocene (Blow's Zones N.9-N.15)}

Foraminifera Used For Biostratigraphic Zonation

Early middle Miocene (N.9-N.12): Globigerinoides bollii, G. obliquus obliquus, Globorotalia fohsi peripheroronda, G. mayeri, G. praemenardii archaeomenardii (lowermost middle Miocene), Globoquadrina spp., Globigerinita dissimilis, and Orbulina spp.

Late middle Miocene (N.13-N.15): Globigerina nepenthes, Globigerinoides spp., Globorotalia fohsi-group, $G$. continuosa, G. mayeri, G. praemenardii praemenardii, Globoquadrina spp., Orbulina spp., and Sphaeroidinellopsis grimsdalei.

Occurrence of Middle Miocene Sediments

Site 239: Present in Core 8 according to the nannofossils. Foraminifera were not identified for reasons dealt with in the site report. Only one specimen of Globorotalia fohsi peripheroacuta together with several long ranging Miocene species were found.
Site 240: Not present.

Site 241: Zones N.9-N.12 are identifiable in Cores 15-13. All foraminiferal assemblages are incomplete because of strong calcium carbonate dissolution. Late middle Miocene is present but not identifiable with foraminifera.

Site 242: Early middle Miocene (N.9-N.14) is present in Core 7, late middle Miocene was not cored; boundary between middle and late Miocene is in Core 6, CC. Foraminiferal faunas are sufficiently well preserved and nearly complete.

Site 245: Not present.

Site 246: Probably Zone N.9, heavily mixed, in Core 3, CC.

Site 248: Not present.

Site 249: Early middle Miocene missing; late middle Miocene, about Zone N.12-N.15, present from Core 16, Section 2 to Core 14 (upper part).

Late Miocene (Blow's Zones N.16-N.18)

Foraminifera Used For Biostratigraphic Zonation

Early late Miocene: Globigerina nepenthes, Globigerinoides obliquus extremus, Globorotalia acostaensis, $G$. merotumida, Sphaeroidinellopsis grimsdalei, Sph. subdehiscens subdehiscens, and Candeina nitida praenitida.

Late late Miocene: Globigerina nepenthes, Globigerina bulloides s.l., Globigerinoides conglobatus, G. obliquus s.1., G. ruber, Globorotalia acostaensis tegillata, $G$. crassaformis s.1., G. miocenica s.l., G. margaritae, $G$. multicamerata, G. tumida plesiotumida, G. tumida tumida (uppermost late Miocene), Candeina nitida, Pulleniatina primalis (uppermost late Miocene), and Sphaeroidinellopsis subdehiscens paenedehiscens.

Occurrence of late Miocene Sediments

Site 239: Present beginning with Core 7, but definition of zones from here to Core 5 is possible only by nannofossils. In Core 5, Zone N.17-N.18 is identifiable with foraminifera, in Core 4, Zone N.18, but heavily mixed. For difficulties in determination, see site report.

Site 240: Foraminifera dissolved in the majority of samples. One good fauna of Zone N.18 was found in Core 4.

Site 241: Present from Core 12 upwards but in bad preservation and with many turbidites. It is difficult to decide whether a fauna is authochthonous or not. The well-preserved foraminiferal assemblages are probably allochthonous, whereas the nearly dissolved faunas are residual; the water depth of the site is 4070 meters.

Site 242: Zone N.16 is present in Core 6 with a well-preserved, highly diversified planktonic fauna, the fossils of Zone N.17 in Core 5 show initial solution of calcium carbonate, those of Zone N.18 are somewhat better preserved. Regarding the preservation and composition of the foraminiferal faunas, Hole 242 would be valuable for special biostratigraphic investigation; however, cores were taken very discontinuously.

Site 245: No fossils.

Site 246: No cores.

Site 248: Nearly complete dissolution of the foraminifera. In Core 4, CC and in Core 6 there are some foraminifera of late Miocene age. 
Site 249: An apparently complete late Miocene section with excellently preserved and highly diversified foraminiferal assemblages was nearly continuously cored (Cores 1 through 13, 130 m).

\section{Pliocene (Blow's Zones N.19-N.21)}

Foraminifera used for Biostratigraphic Zonation

A large number of typical Miocene foraminifera is still present in the Pliocene sediments. The most frequent and/or characteristic species are Globorotalia crassaformis and variants, G. multicamerata, Globoquadrina altispira altispira, Pulleniatina primalis, P. obliquiloculata praecursor, Sphaeroidinella dehiscens immatura, and Sph. dehiscens dehiscens. In the lower part of the Pliocene Globigerina bulloides apertura, G. nepenthes, Globorotalia margaritae, and Sphaeroidinellopsis spp. are disappearing; in the upper part, Globorotalia inflatal puncticulata, G. tosaensis, and Pulleniatina obliquiloculata obliquiloculata appear.

Occurrence of Pliocene Sediments

Site 239: Present in Core 3 but mixed with middle Miocene material.

Site 240: Not identifiable but probably present; foraminifera are dissolved.

Site 241: Present but mixed and poorly preserved.

Site 242: Present and well preserved but only spot cored. Site 245: Not present.

Site 246: Present in one mixed sample, Core 2.

Site 248: Very incomplete, dissolved fauna in Core 4.

Site 249: Probably present, but highly mixed and condensed in Core 1 , Section 1.

\section{Quaternary Biostratigraphy}

It was hoped that a detailed biostratigraphic subdivision of the Quaternary material recovered during Leg 25 could be made. This would have advanced the knowledge of the, as yet little known, paleoclimatic history of the region. The potential appeared good because a thick Quaternary section was cored in at least one site (Table 4). However, all cores containing Quaternary sediments had undergone extensive mechanical mixing during drilling. Each faunal assemblage is a mixture of cool- and warm-water planktonic foraminifera. It is, therefore, impossible to distinguish between cool and warm periods.

Table 5 demonstrates the mixed nature of the foraminiferal associations in the samples by the very uniform percentage for all species. The near-surface sample is the only one which differs, showing higher percentages of

TABLE 4

Thickness of Quaternary Sediments

\begin{tabular}{|c|c|c|c|}
\hline \multicolumn{4}{|c|}{ Thickness (m) } \\
\hline Site & Minimum & & Maximum \\
\hline 239 & $>6$ & & $<18$ \\
\hline 240 & $>9$ & & $<70$ \\
\hline 241 & & $\sim 70$ & \\
\hline 242 & $>6$ & & $<50$ \\
\hline 245 & & $<1$ & \\
\hline 246 & $>4$ & & $<52$ \\
\hline 248 & $>5$ & & $<120$ \\
\hline 249 & & $\sim 2$ & \\
\hline
\end{tabular}

foraminifera that indicate warmer conditions. If the ${ }^{14} \mathrm{C}$-ages give the correct ages of unmixed samples, high values of Globigerinoides ruber and Pulleniatina obliquiloculata would be expected in at least Sections 1 through 3 . This would agree with the results from piston cores from the western Indian Ocean (Zobel, 1973, and unpublished data from cores from the Somali Basin). In these piston cores, sediments, especially those from the early Holocene (ages of about $6000-8000{ }^{14} \mathrm{C}$-years), yield a high percentage of warm-water foraminifera, whereas the late Pleistocene differs decidedly by having a high percentage of cool-water foraminifera. In the samples from Site 241 , there is practically no difference between the presumably early Holocene and the late Pleistocene samples.

Assuming the ${ }^{14} \mathrm{C}$-ages are correct, there would have been a sedimentation rate of $560 \mathrm{~m} / 10^{6}$ years or about 1,000 meters of sediment accumulating during the Quaternary. In reality, the thickness of the Quaternary in Site 241 is about 70 meters. We must therefore conclude that, in spite of the favorable-appearing ${ }^{14} \mathrm{C}$-ages, the upper cores of Site 241 contain totally mixed sediments. This example characterizes all holes from Leg 25.

\section{BIOSTRATIGRAPHIC CORRELATION}

Correlation of the biostratigraphic units in the Neogene and Quaternary parts of the holes is shown in Figure 2. Plotted for each site are the section cored, the sediment recovery, and the biostratigraphic zonation. The correlation lines from site to site connecting equivalent biostratigraphic units are nearly all dashed, indicating that the exact position of the boundary between two units is not known due, in most cases, to missing cores. When the boundary was found in the core, the line is solid and not dashed.

The sites are arranged according to their geographic position; Sites 241,242 , and 248 are situated in deep water next to the continental margin of Africa. Consequently, they show thick, and relatively undisturbed, sediment accumulation with a complete succession of biozones. Sites 249 and 246 lie on plateaus. Here, the sediment accumulation, at least at times, was hampered so that biozones can be missing or condensed. Sites 240, 239, and 245 , although located in deep basins far off the African continent, do not show the quiet pelagic sedimentation which are expected. That may be due to their proximity to relatively mobile zones beneath the Indian Ocean.

Boundaries determined by nannoplankton and foraminiferal zonation correspond much better than expected. Except for the generally somewhat lesser age of the nannoplankton zones in the late Neogene, there are only minor differences. At Site 241, the boundary between early and middle Miocene is farther up in the core, according to the nannoplankton zonation, whereas the boundary between Paleogene and Neogene is deeper. The latter may be due to the fact that the NP $25 / \mathrm{NN} 1$ boundary was considered synonymous with the Paleogene/Neogene boundary. According to Berggren (1972) NP $25 / \mathrm{NN} 1$ is already within the late Oligocene. This could account for the different determinations of the Paleogene/Neogene by paleontologists working with nannoplankton or foraminifera. 


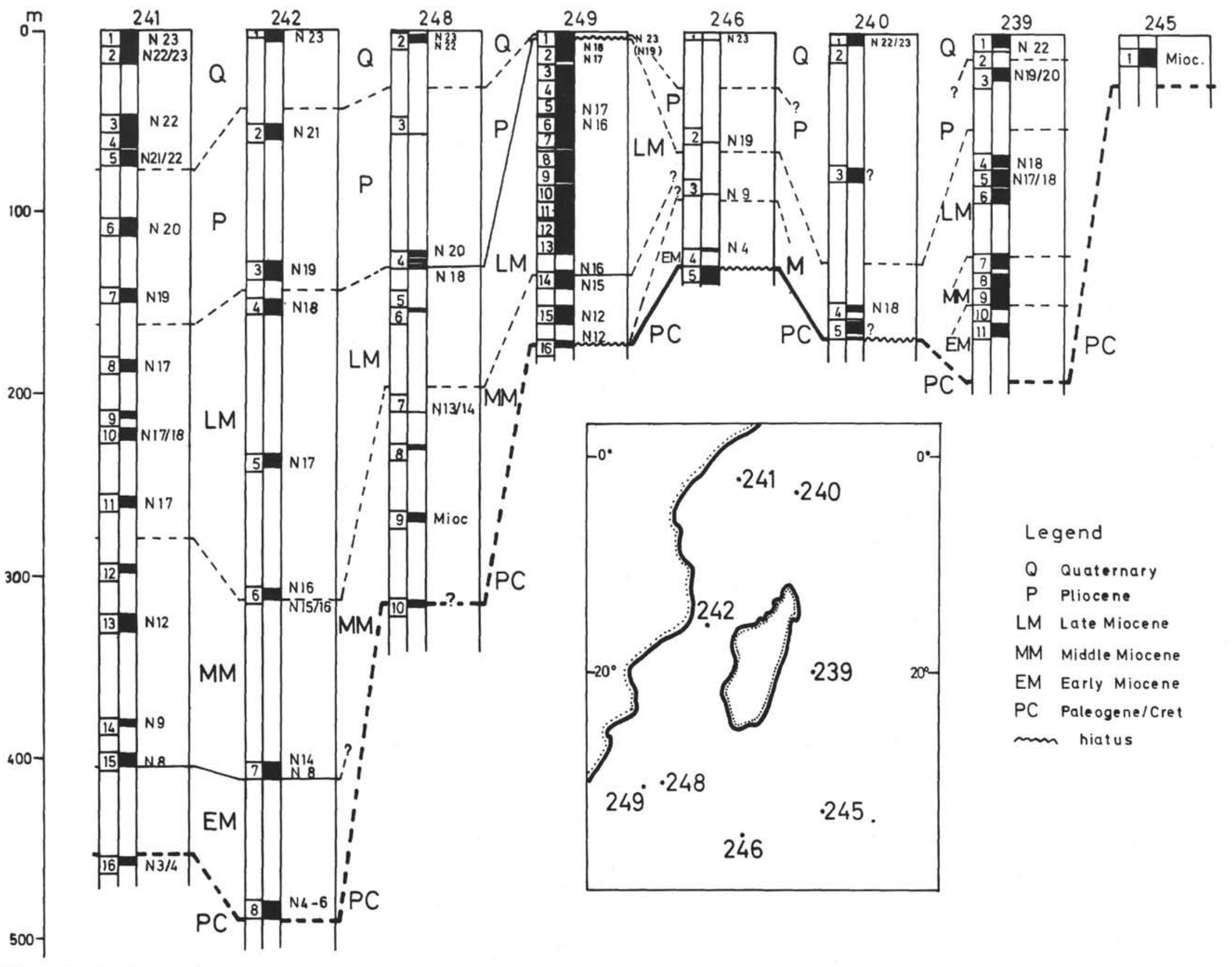


TABLE 5

Important Planktonic Foraminifera, Percentage Abundance, Site 241, Core 1 Samples

\begin{tabular}{|c|c|c|c|c|c|c|c|c|c|}
\hline $\begin{array}{l}\text { Core, Section, } \\
\text { Interval in } \mathrm{cm}\end{array}$ & 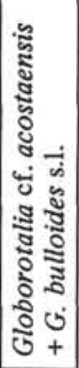 & 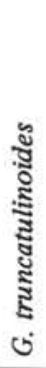 & 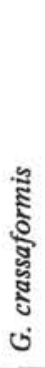 & 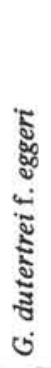 & 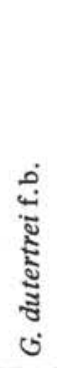 & 怠 & 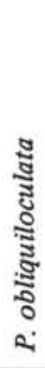 & 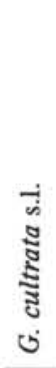 & ${ }^{14} \mathrm{C}$-ages ${ }^{\mathrm{a}}$ \\
\hline $1-1,0-2$ & 8 & 3 & 5 & 5 & 10 & 9 & 11 & 31 & \\
\hline $1-1,2-17$ & - & - & - & - & - & - & - & - & $5015 \pm 790$ \\
\hline $1-1,100-102$ & 10 & 1 & 7 & 13 & 10 & 8 & 9 & 21 & \\
\hline $1-2,50-52$ & 14 & 3 & 6 & 9 & 8 & 9 & 10 & 26 & \\
\hline $1-3,100-102$ & 14 & 2 & 5 & 10 & 8 & 9 & 9 & 23 & \\
\hline $1-4,50-52$ & 13 & 3 & 7 & 10 & 10 & 5 & 9 & 25 & \\
\hline $1-4,110-125$ & - & - & - & - & - & - & - & - & $10130 \pm 1270$ \\
\hline $1-4,138-140$ & 12 & 0 & 3 & 15 & 6 & 5 & 8 & 23 & \\
\hline $1-6,100-117$ & - & - & - & - & - & - & - & - & $13450 \pm 805$ \\
\hline $1-6,148-150$ & 11 & 3 & 5 & 19 & 5 & 5 & 7 & 26 & \\
\hline
\end{tabular}

Note: Percentages are based on counts of $\sim 400$ individuals larger than 177 microns per sample.

${ }^{\mathrm{a}}{ }^{14} \mathrm{C}$ -

Bodenforschung.

At Site 242, the boundary between Paleogene and Neogene is clearly established by the nannoplankton zonation, whereas the foraminifera indicate a broad transitional zone.

At Site 249 the Pliocene, as determined with foraminifera, could not be verified by nannoplankton fossils. The discrepancies between nannoplankton and foraminifera zones in the middle Miocene of this hole will require further investigation.

\section{REFERENCES}

Berggren, W. A., 1972. A Cenozoic time-scale-some implications for regional geology and paleobiogeoggraphy: Lethaia, v. 5, p. 195-215.
Blow, W. H., 1969. Late Middle Eocene to Recent planktonic foraminiferal biostratigraphy: Internat. Conf. Plankt. Microfossils, 1st, Proceed, Brönnimann and Renz (Eds.), Leiden, (Brill, E. J.), v. 1, p. 199-422.

Bolli, H. M., 1966. Zonation of Cretaceous to Pliocene marine sediments based on planktonic foraminifera: Assoc. Venezolana Geol. Min. Petrol., Bol. Inform., v. 9 (1), p. 3-32.

Jenkins, D. G. and Orr, W. N., 1972. Planktonic foraminiferal biostratigraphy of the eastern equatorial Pacific, Leg 9. In Hays. J. D. et al., Initial Reports of the Deep Sea Drilling Project, Volume IX; Washington (U. S. Government Printing Office), p. 1059-1193.

Zobel, B., 1973. Biostratigraphische Untersuchungen an Sedimenten des indisch-pakistanischen Kontinentalrandes (Arabisches Meer): "Meteor" Forsch. Ergeb., Reihe C, No. 12, p. 9-73, Berlin. 